
DOI: http://dx.doi.org/10.4314/njbas.v24i1.2

\title{
Gastroprotective Activities of the n-Hexane Fraction of Heliotropium indicum on Gastric Ulceration
}

\author{
${ }^{* 1}$ M.D. Ayoola, ${ }^{2}$ A.A. Akinlolu, ${ }^{3}$ S. Adeboga and 4 J.O. Otulana \\ 'Department of Pharmacognosy, Faculty of Pharmacy, Obafemi Awolowo University, Ile-lfe, Osun State, Nigeria. \\ 2Department of Anatomy, University of llorin, Kwara State, Nigeria. \\ 3Department of Pharmacognosy, Faculty of Pharmacy, Olabisi Onabanjo University, Ogun State, Nigeria. \\ ${ }^{4}$ Department of Anatomy, Olabisi Onabanjo University, Ogun State, Nigeria. \\ [Corresponding Author: Email: ayoolamd@oauife.edu.ng; : +234 7030949601]
}

\begin{abstract}
Heliotropium indicum has been established to possess gastroprotective properties. We evaluated the gastroprotective properties of the non-polar (n-hexane) fraction of $H$. indicum to establish its anti-ulcer activities. Rats of Groups I and II received physiological saline and $80 \mathrm{mg} / \mathrm{kg} / \mathrm{body}$ weight (bw) of Indomethacin respectively. Rats of Groups III - VI received orally 100, 200 and $400 \mathrm{mg} / \mathrm{kg} / \mathrm{bw}$ of the $\mathrm{n}$ - hexane fraction of methanolic extracts of dried leaves of $H$. indicum and $50 \mathrm{mg} / \mathrm{kg} / \mathrm{bw}$ of Ranitidine respectively before the induction of gastric ulceration. One hour after administration of extract doses and Ranitidine, $80 \mathrm{mg} / \mathrm{kg} / \mathrm{bw}$ of Indomethacin (an ulcerogen) was administered orally to rats of Groups III - VI. Morphological analyses show that administrations of 100, 200 and $400 \mathrm{mg} / \mathrm{kg} / \mathrm{bw}$ of extract and Ranitidine resulted in percentage ulcer reductions of $45 \%, 50 \%, 75 \%$ and $95 \%$ respectively. Histological analyses of the stomach in rats of Groups II and III show erosion of mucus-secreting cells, parietal cells, gastric pit and glands. Erosion of few mucus-secreting cells, gastric pit and parietal cells were observed in rats of Group IV. Normal cytoarchitectures of the mucosa layer were observed in rats of Groups I, $\mathrm{V}$ and $\mathrm{VI}$. Our findings show that the n-hexane fraction of $H$. indicum possessed gastroprotective properties.

Keywords: Heliotropium indicum, Indomethacin, Ulceration.
\end{abstract}

\section{INRODUCTION}

Peptic ulcer occurs in sections of the gastro intestinal tract exposed to gastric acid and pepsin, such as the stomach and duodenum. The etiology is not clearly known. It results probably from an inbalance between aggressive (acid, pepsin and $\mathrm{H}$. pylori infection) and defensive (gastric mucus and bicarbonate secretion, prostaglandins, nitric oxide, innate resistance of the mucosal cells) factors; as well as factors such as genetic, psychosomatic, humoral and vascular derangements (Ramzi, 1999). Pathological examination of gastric ulcer could be evaluated in any part of the stomach, but is most commonly obtained from the lesser curvature. Histologically, there is a break in the superficial epithelium penetrating down to the muscularis mucosa with a fibrous base accompanied with increase in inflammatory cells (Ramzi, 1999)

Heliotropium indicum belongs to the family Boraginaceae. Other species of Heliotropium include Heliotropium bacciferum, Heliotropium ovalifolium and Heliotropium pterocarpum (Burkhill, 1985). It grows up to $80 \mathrm{~cm}$ high with a pleasant aroma. Its stems and leaves are covered with a fine hairy layer, and its flowers are small and grow in clusters which curve in on themselves at the tips (Burkhill, 1985) It is found in tropical and non-tropical countries bearing various names, such as Cock's comb (Gambia), Indian heliotrope, herbe a verrues (France), Heliotropio-inIndiano (Portugal) and Agogo Igun or Ogbe Akuko (Yoruba - Nigeria) (Burkhill, 1985) Its chemical components include pyrolizidine alkaloids, indicine-N-oxide, tannins, saponins and heliotrine (Burkhill, 1985).

Its alkaloid component confers on it anti-inflammatory, wound healing, antiseptic/antimicrobial, febrifuge, secretagogue stimulation of gall bladder and menstruation activator properties (Burkhill, 1985; Sofowora, 1993). It is most important local application is for skin lesions, wounds, abscesses, gastric and varicose ulcerations, rashes and warts (Burkhill, 1985; Sofowora, 1993). It also shows anti leukemia activity, but hepatotoxicity negates its usefulness (Burkhill, 1985; Sofowora, 1993).

The crude aqueous extract of $H$. indicum has dosedependent morphological gastroprotective effects on indomethacin - induced gastric ulcerated mucosa in male wistar rats (Akinlolu et al., 2006). The present study, therefore, investigated the gastroprotective properties of the non-polar (n-hexane) fraction of the methanolic extract of $H$. indicum in order to establish its anti-ulcer activities.

\section{MATERIALS AND METHODS}

\section{Collection and Authentication of $\mathrm{H}$. Indicum}

$H$. indicum of the family Boraginaceae was collected in Sagamu, Ogun State in the South West of Nigeria. The plant was identified and authenticated at the Forest Research Institute of Nigeria Ibadan. The authenticated plant has the Voucher number FHI 107093. 


\section{Care and Feeding of Animals}

Adult male wistar rats weighing between $90-150 \mathrm{~g}$ were obtained from the colony bred of the Physiology Department of Obafemi Awolowo University, lle -lfe, Nigeria. Animals were fed during the experiment with growers feed from Bendel Feed and Flour Mill Ltd., Nigeria. The animals were caged under standard condition in the well ventilated animal house of the Faculty of Pharmacy, Olabisi Onabanjo University, Ogun State, Nigeria at room temperature $\left(25^{\circ} \mathrm{C}\right)$ Water was supplied ad libitum to the rats. Ethical approval was sought and received from the Ethical Committee of the Faculty of Pharmacy of Olabisi Onabanjo University, Nigeria on the usage of animals for experimental studies.

\section{Preparation of Plant Extracts}

The leaves of $H$. indicum were air dried for nine days under shade and powdered using a laboratory blender. The powdered leaf $(250 \mathrm{~g})$ was soaked in 1 (one) litre of methanol in a glass jar for the first three days, then soaked in another 1 (one) litre of methanol for the next two days and soaked lastly in 0.5 litres of methanol for another two days. The different methanolic extract fractions were collected, added together and concentrated using the Rotary evaporator at a temperature of $55^{\circ} \mathrm{C}$. The methanolic extract was then finally dried on the hot plate at a reduced temperature. The methanolic extract was then dissolved in a methanol:water mixture ratio of 1:3. This was partitioned with $\mathrm{n}$ - Hexane to separate the non-polar fraction from the polar fraction of the extract. The partitioning gave the aqueous solution fraction and the $n$ - hexane soluble fraction which were separately concentrated on a water bath to dryness and then kept under suitable conditions $\left(10^{\circ} \mathrm{C}\right.$ to $\left.20^{\circ} \mathrm{C}\right)$ for further bioactivity studies. The yield was calculated for each of the fractions.

\section{Phytochemical Evaluations: Test for Saponins}

The powdered sample of the n-hexane fraction of $H$. indicum $(1 \mathrm{~g})$ was boiled with $10 \mathrm{mls}$ distilled water for 10 minutes and filtered while hot, then allowed to cool. $2.5 \mathrm{ml}$ of the filtrate was diluted with $10 \mathrm{ml}$ of water and shaken properly, and then two drops of castor oil were added to the solution and shaken vigorously for 2 minutes. A stable emulsion was formed and there was frothing indicating that the result was positive (Evans and Trease, 2002).

\section{Phytochemical Evaluations: Test for Tannins}

The powdered sample $(0.5 \mathrm{~g})$ of the n-hexane fraction of $H$. indicum was boiled with $10 \mathrm{ml}$ of distilled water for 5 minutes, filtered while hot and cooled. The filtrate was adjusted to $20 \mathrm{ml}$ with distilled water. One $\mathrm{ml}$ of the filtrate was further diluted with distilled water to $5 \mathrm{ml}$, after which a few drops of $0.1 \%$ ferric chloride solution were added. A bluish-black or greenish colour indicates a positive test (Evans and Trease, 2002; Rojas et al., 2006).

\section{Gastro-protective Activity of $H$. indicum}

Feeding of the animals was terminated 24 hours before the commencement of experimental procedures. The animals were, however, allowed free access to water and were then randomly divided into six treatment groups of four rats each. Two (2) $\mathrm{ml}$ of normal saline was administered orally to rats of Control Group I, $80 \mathrm{mg} / \mathrm{kg} / \mathrm{bw}$ of Indomethacin (Hovid, Nigeria) was administered orally to rats of Experimental Group II, $\mathrm{n}$ - hexane fraction of the methanolic extract of $H$. indicum at doses of 100,200 and $400 \mathrm{mg} / \mathrm{kg} / \mathrm{bw}$ were administered orally to rats of Experimental Groups III, IV and $V$ respectively while $50 \mathrm{mg} / \mathrm{kg} / \mathrm{bw}$ of Ranitidine (Glaxowellcome, Egypt) was administered orally to rats of Experimental Group VI as the standard control or positive group.

One hour after administrations of 100, 200 and 400 $\mathrm{mg} / \mathrm{kg} / \mathrm{bw}$ of $H$. indicum and $50 \mathrm{mg} / \mathrm{kg} / \mathrm{bw}$ of Ranitidine; 80 $\mathrm{mg} / \mathrm{kg} / \mathrm{bw}$ of Indomethacin was administered orally to rats of Groups III - VI (Adesanwo et al, 2003; Raji et. al., 2003). After four hours, the animals were sacrificed by cervical dislocation and the stomach of each rat was removed. The stomach was opened along the lesser curvature and washed with normal saline to remove any debris (Adesanwo et al, 2003; Raji et. al., 2003). Assessment of gastric ulceration was done by means of "scoring technique" as earlier described (Raji et. al., 2001).

The ulcer scoring system is as shown below: 0.0 -Normal stomach 0.5 -Punctuate or pinpoint hemorrhagic ulcer 1.0 -Two or more hemorrhagic ulcers 2.0 -Ulcers greater than $3 \mathrm{~mm}$ in diameter.

Macroscopic examination of the stomach was carried out with a hand lens of X2 magnification (Raji et. al., 2001).

\section{Histopathological Examinations}

The excised stomach of rats of Groups I - VI were kept in $10 \%$ formol-saline. Three to five $\mu \mathrm{m}$ thick sections of the stomach samples were cut on a Reichert-Jung 2050 rotary microtome (Cambridge Instruments, Germany). Sections were floated on water bath at $50^{\circ} \mathrm{C}$ and mounted on prewashed, sterilized 25.4 X $76.2 \mathrm{~mm}$ glass slides (Pearls, China). Sections were stained with haematoxylin and eosin as described by Kiernan (1990) and modified by Akinlolu et al. (2008). 


\section{Statistical Analyses}

Computed data were expressed as Mean \pm S.E.M. Computed Means were compared using paired sample students't- test. Data were analyzed using Microsoft Excel 2007 (Microsoft Corporation, USA).

\section{RESULTS}

\section{Gross Morphological Analyses}

Indomethacin induced a morphological ulcer score of 2.0 in all rats of Group II that received only $80 \mathrm{mg} / \mathrm{kg} / \mathrm{bw}$ of Indomethacin. Gross morphological analyses show that the n-hexane fraction of the methanolic extracts (at doses of 100,200 and $400 \mathrm{mg} / \mathrm{kg} / \mathrm{bw}$ ) of the dried leaves of $H$. indicum protected against $80 \mathrm{mg} / \mathrm{kg} / \mathrm{bw}$ of Indomethacininduced gastric ulceration in treated rats of Groups III - V in a dose-dependent manner. Gross morphological analyses show that administrations of 100,200 and $400 \mathrm{mg} / \mathrm{kg} / \mathrm{bw}$ of $\mathrm{H}$. indicum and Ranitidine resulted in percentage ulcer reduction of $45 \%, 50 \%, 75 \%$ and $95 \%$ respectively.

\section{Histological Analyses}

Histological evaluations were carried out on the stomach of each rat using routine laboratory haematoxylin and eosin method (Kiernan, 1990) to evaluate the histogastroprotective effects of $H$. indicum on Indomethacin induced gastric ulcerated mucosa of wistar rats. None of the rats used in this study died while the experimental procedures lasted. Thus, all rats were histologically examined to evaluate the degree of ulceration, degree of gastro-protection and other intrinsic histopathological alterations on the mucosal lining of the stomach. Photomicrograph of histo-pathological examinations of the stomach sections of rats of Groups I - VI are presented in Figures $1-6$.

Histological analyses of the stomach body walls in rats of Groups II and III that received $80 \mathrm{mg} / \mathrm{kg} / \mathrm{bw}$ of Indomethacin only and $100 \mathrm{mg} / \mathrm{kg} / \mathrm{bw}$ of $H$. indicum show erosion of the mucus-secreting cells, gastric pit, upper and middle parts of gastric glands and the parietal cells. Histological observations of the stomach body walls in rats of Group IV that received $200 \mathrm{mg} / \mathrm{kg} / \mathrm{body}$ weight of $H$. indicum show erosion of few mucus-secreting cells, gastric pit and the parietal cells. Histological observations of the stomach body walls in rats of Groups I, V and VI that received 80 $\mathrm{mg} / \mathrm{kg} / \mathrm{body}$ weight of Normal Saline, $400 \mathrm{mg} / \mathrm{kg} / \mathrm{body}$ weight of $\mathrm{H}$. indicum and $50 \mathrm{mg} / \mathrm{kg} /$ body weight of Ranitidine respectively show normal morphological appearances of the different components of the mucosa layer. Therefore, the n-hexane fraction of the methanolic extracts of the dried leaves of $H$. indicum had dose dependent gross morphological and histo-gastroprotective effects against Indomethacin- induced gastric ulceration.

Table 1: Doses of $H$. indicum/Drug Received by Experimental Rats and Ulcer Parameters, degree of ulceration and percentage of ulcer reduction in rats

\begin{tabular}{clccc}
\hline Groups of Rats & $\begin{array}{l}\text { Dosage of } \\
(\mathrm{mg} / \mathrm{kg} / \mathrm{bw})\end{array}$ & $\begin{array}{c}\text { Mean Ulcer Score } \\
( \pm \text { SEM) }\end{array}$ & $\begin{array}{c}\text { Degree of } \\
\text { Ulceration }\end{array}$ & $\begin{array}{c}\text { Ulcer Reduction } \\
(\%)\end{array}$ \\
\hline I & 2mls Normal Saline & $0.00 \pm 0.00$ & 0 & - \\
II & 80mg Indomethacin & $2.00 \pm 0.00$ & 40 & 0 \\
III & 100mg/kg/bw H. indicum & $2.00 \pm 0.00$ & 30 & 45 \\
IV & $200 \mathrm{mg} / \mathrm{kg} / \mathrm{bw}$ H. indicum & $1.10 \pm 0.24$ & 22 & 50 \\
V & $400 \mathrm{mg} / \mathrm{kg} / \mathrm{bw}$ H. indicum & $1.00 \pm 0.27$ & 20 & 75 \\
VI & $50 \mathrm{mg} / \mathrm{kg} / \mathrm{bw}$ Ranitidine & $0.50 \pm 0.22$ & 10 & 95 \\
\hline
\end{tabular}

S.E.M. = Standard Error of Mean of 4 determination,, bw = body weight, $H$. Indicum = Heliotropium indicum . 


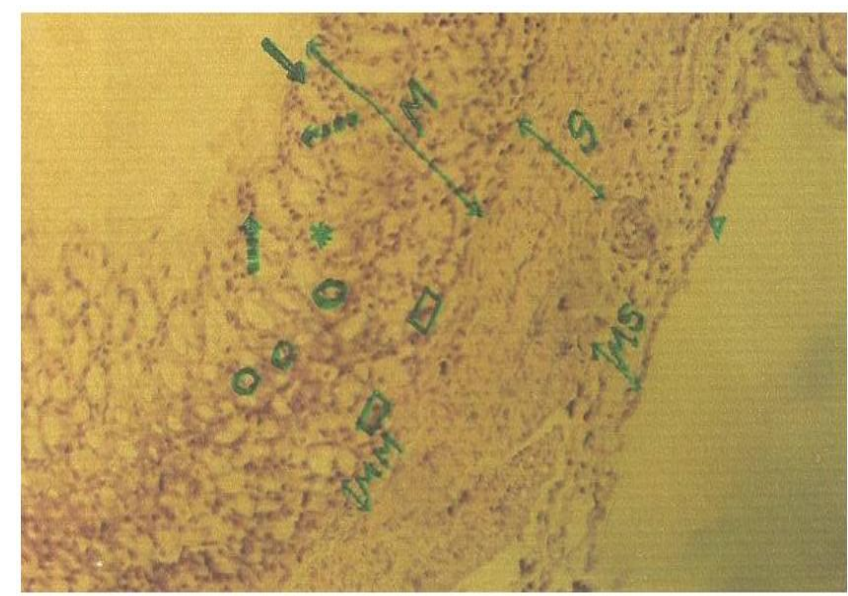

Figure 1: Photomicrograph sample of the stomach bodywall in rats of Group I which received only physiological saline. Haematoxylin and Eosin X 800. The Solid Arrow is on the gastric pit, the broken arrow is on the mucus secreting cells, the star sign is on the gastric gland, the circle sign is on parietal cells and the square sign is on peptic cells. $M=$ Gastric Mucosa, $M M=$ Muscularis Mucosae, $S=$ Submuscularis and MS = Muscularis Layer and the triangle sign points to the Serosa. Histological observations of the stomach body wall show normal morphological appearance of the different components of the mucosa layer.

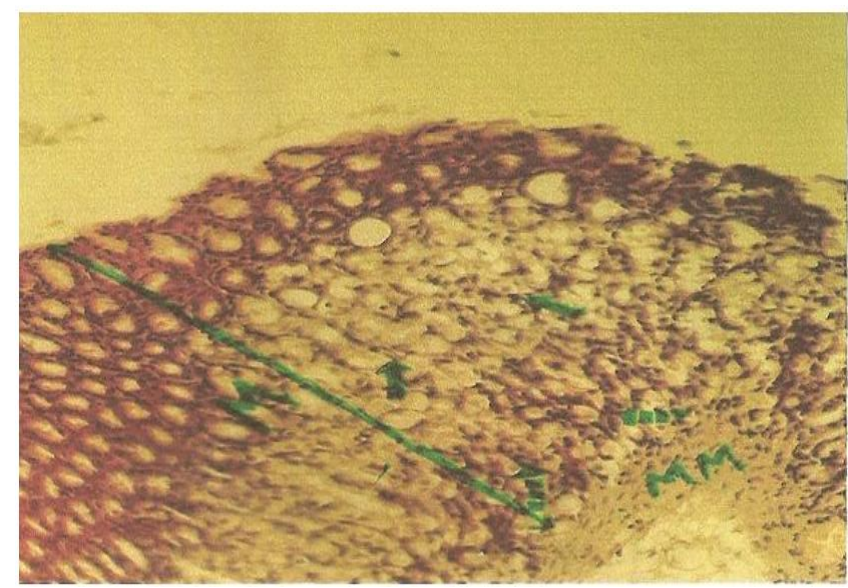

Figure 3: Photomicrograph sample of rats in Group III which received oral administration of $100 \mathrm{mg} / \mathrm{kg} / \mathrm{bw}$ of extract of Heliotropium indicum prior to receiving further oral administration of $80 \mathrm{mg} / \mathrm{kg} / \mathrm{bw}$ of Indomethacin. Haematoxylin and Eosin X 800. The solid arrow is on the parietal cells, the broken arrow is on the peptic cells. $M=$ Gastric Mucosa, and MM = Muscularis Mucosae. Histological analyses of the stomach body wall show erosion of the mucus-secreting cells, gastric pit and parietal cells. The stomach mucosa is ulcerated.

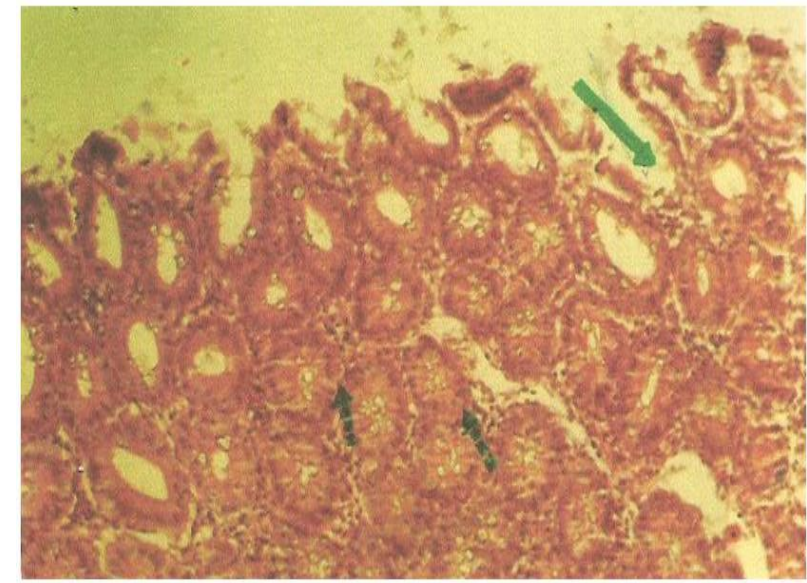

Figure 2: Photomicrograph sample of the stomach bodywall in rats of Group II which received oral administration of 80 $\mathrm{mg} / \mathrm{kg} / \mathrm{bw}$ of Indomethacin without prior oral administration of any dosage of extract of Helicotropium Indicum. Haematoxylin and Eosin X 800. The solid arrow is on the base of a gastric gland. The broken arrow on the peptic cells. Histological analyses of the stomach bodywall show erosion of mucus-secreting cells, gastric pit, upper and middle parts of gastric glands and the parietal cells. The stomach mucosa is ulcerated.

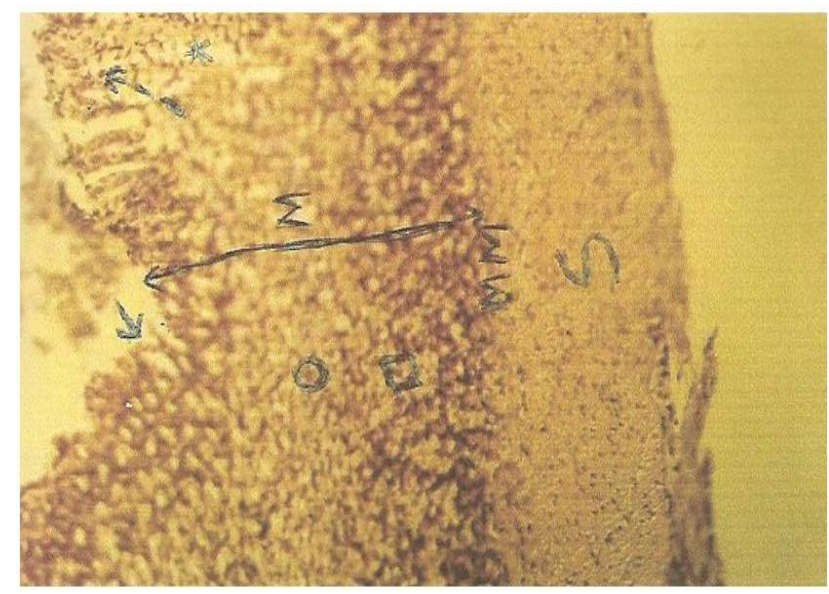

Figure 4: Photomicrograph sample of stomach bodywall of rats in Group IV which received oral administration of 200 $\mathrm{mg} / \mathrm{kg} / \mathrm{bw}$ of extract of Heliotropium indicum prior to receiving further oral administration of $80 \mathrm{mg} / \mathrm{kg} / \mathrm{bw}$ of Indomethacin. Haematoxylin and Eosin X 800. The solid arrow is on the upper part of the gastric gland, the broken arrow is on the mucous secretion cells, the star sign is on the gastric gland, the circle sign is on parietal cells and the square sign is on peptic cells. $M=$ Mucosa. $M M=$ muscularis mucusa, and $\mathrm{S}=$ submuscularis Histological observations of the stomach body wall show mild erosion of few mucus-secreting cells, gastric pit and parietal cells. 


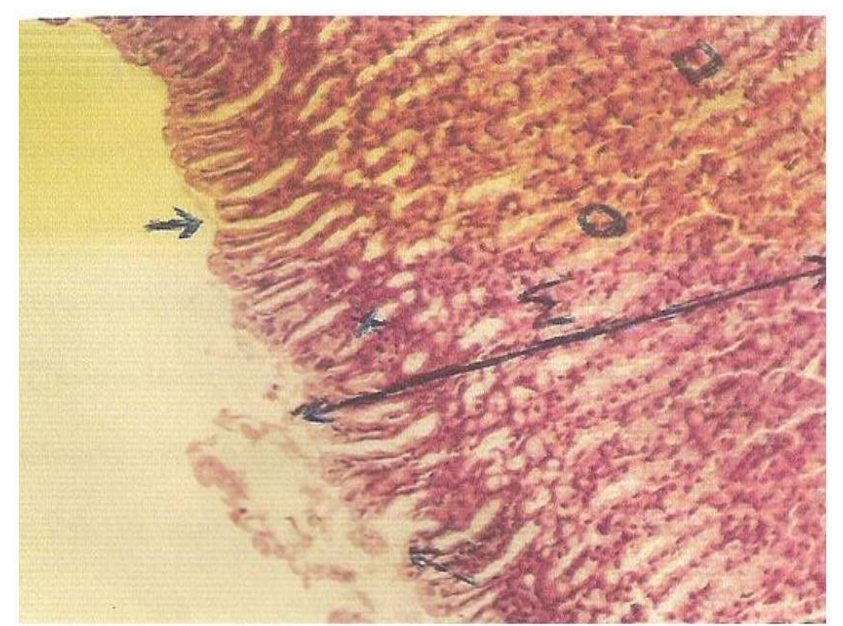

Figure 5: Photomicrograph sample of stomach bodywall of rats in Group V which received oral administration of 400 $\mathrm{mg} / \mathrm{kg} / \mathrm{bw}$ of extract of Heliotropium indicum prior to receiving further oral administration of $80 \mathrm{mg} / \mathrm{kg} / \mathrm{bw}$ of Indomethacin. Haematoxylin and Eosin X 800. The solid arrow is on gastric pit, the broken arrow is on mucous secreting cells, the star sign is on the gastric gland, the circle sign is on parietal cells and the square signs is on peptic cell. $\quad \mathrm{M}=$ Gastric Mucosa. Histological observations of the stomach body wall show normal morphological appearance of the different components of the mucosa layer.

\section{DISCUSSION}

Indomethacin is an established ulcerogen, especially in an empty stomach (Evbuonwan and Bolarinwa, 1991; Akinlolu et al., 2008). The incidence of Indomethacin induced ulceration is mostly predominant in the glandular (mucosal) part of the stomach (Akinlolu et al., 2008). Although, the mechanisms underlying the ulcerogenicity of indomethacin are not completely understood; it has been known that indomethacin induces gastric mucosa ulceration through inhibition of prostaglandins synthesis (John, 2000; Akinlolu et al., 2008). This view is supported by the fact that several prostaglandins and prostaglandin analogues are potent antisecretory and anti-ulcer agents. Prostaglandins normally serve protective functions in the stomach by maintaining gastric micro circulation via mucus and bicarbonate stimulation (John, 2000; Sabiha et al., 2011).

Indomethacin stimulates catecholamines release from adrenal medulla, resulting in mucosal vasoconstriction (John, 2000; Sabiha et al., 2011). It has also been established to uncouple mitochondrial respiration resulting in depletion of Adenosine Triphosphate and a reduced potential of gastric epithelial cells to coordinate normal cellular functions (John, 2000; Sabiha et al., 2011). Hence,

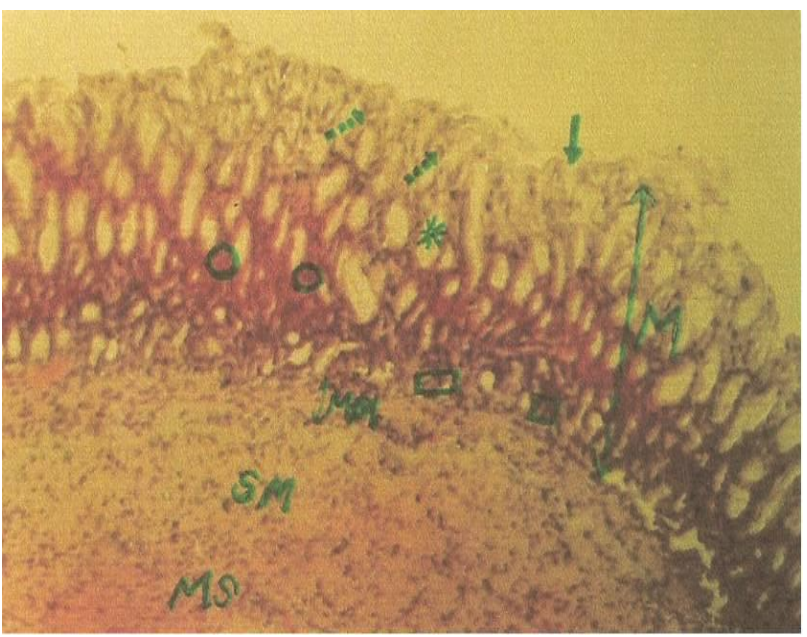

Figure 6: Photomicrograph sample of the stomach bodywall in rats of Group VI which received oral administration of 50 $\mathrm{mg} / \mathrm{kg} / \mathrm{bw}$ of Ranitidine prior to receiving further oral administration of $80 \mathrm{mg} / \mathrm{kg} / \mathrm{bw}$ of Indomethacin. Haematoxylin and Eosin X 800. The solid arrow is on the gastric pit, the broken arrow is on mucous secreting cells, the star sign is on the gastric gland, the circle sign is on parietal cells and the square sign is on peptic cells. $M=$ Gastric Mucosa, $\mathrm{MM}=$ Muscularis Mucosae, $\mathrm{SM}=$ Submuscularis and MS = Muscularis Layer. Histological observations of the stomach body wall in rats show normal morphological appearance of the different components of the mucosa layer.

Indomethacin reduces both the quality as well as amount of mucus secretion and changes in ionic permeability characteristics of gastric mucosa (John, 2000; Akinlolu et al., 2008)

Indomethacin induced a morphological ulcer score of 2.0 in all rats of Group II that received only $80 \mathrm{mg} / \mathrm{kg} / \mathrm{bw}$ of Indomethacin. Gross morphological analyses show that the $\mathrm{n}$ - hexane fraction of the methanolic extracts (at doses of 100,200 and $400 \mathrm{mg} / \mathrm{kg} / \mathrm{bw}$ ) of leaves of $H$. indicum protected against indomethacin- induced gastric ulceration in treated rats of Groups III - V in a dose - dependent manner. Gross morphological analyses show that administrations of 100,200 and $400 \mathrm{mg} / \mathrm{kg} / \mathrm{bw}$ of $H$. indicum and Ranitidine resulted in percentage ulcer reduction of $45 \%, 50 \%, 75 \%$ and $95 \%$ respectively. Our findings are in agreement with earlier studies which noted percentage ulcer reductions in treatment with leaf extracts of $H$. Indicum (Akinlolu et al., 2008; Ashoka et al., 2011).

Histological analyses of the stomach body walls in rats of Groups II and III that received $80 \mathrm{mg} / \mathrm{kg} / \mathrm{bw}$ of Indomethacin only and $100 \mathrm{mg} / \mathrm{kg} / \mathrm{bw}$ of $H$. indicum show erosion of the mucus-secreting cells, gastric pit, upper and middle parts of 
Ayoola et al:: Gastroprotective Activities of the n-Hexane Fraction of Heliotropium indicum on

gastric glands and the parietal cells (Figures 2 and 3 ). Erosion of few mucus-secreting cells, gastric pit and the parietal cells were observed in rats of Group IV that received $200 \mathrm{mg} / \mathrm{kg} / \mathrm{bw}$ of $H$. indicum (Figure 4). Normal morphological appearances of the different components of the mucosa layer were observed in rats of Groups I, $V$ and VI that received $80 \mathrm{mg} / \mathrm{kg} / \mathrm{bw}$ of Normal Saline, 400 $\mathrm{mg} / \mathrm{kg} / \mathrm{bw}$ of $\mathrm{H}$. indicum and $50 \mathrm{mg} / \mathrm{kg} / \mathrm{bw}$ of Ranitidine respectively (Figures 1, 5 and 6 ). Therefore, the $n$-hexane fraction of the methanolic extracts of the dried leaves of $H$. indicum had dose-dependent gross morphological and histo-gastroprotective effects against Indomethacin-induced gastric ulcerations. . These observations are in agreement with our previous study which noted the gastroprotective activity of $H$. Indicum (Akinlolu et al., 2008).

The precise mechanism of action of $\mathrm{H}$. indicum is not clear, however, it has been proposed that mucosal protection induced by non-prostanoid compounds may be mediated through the mobilization of endogenous prostaglandins (Ima et al., 2010; Sabiha et al., 2011) Hence, it is possible that one of the mechanisms of anti-ulcerogenic effect of $H$. indicum might be due to its ability to mobilize endogenous prostaglandins in gastric mucosa.

The phytochemical analyses of the methanolic extract of the n-hexane fraction of $\mathrm{H}$. indicum indicate the presence of tannins and saponins. Tannins being astringent with vasoconstricting effects (Ima et al., 2010; Sabiha et al., 2011; Ateeq et al., 2013) might have precipitated microproteins on the sites of ulcers thereby forming a nonpenetrable protective pellicle over the lining to prevent absorption of toxic substances and resist attack of proteolytic enzymes (Ima et al., 2010; Sabiha et al., 2011; Ateeq et al., 2013). Tannins as phenolic compounds are known to enhance the status of oxidative stress biomarkers with the ability to scavenge free radicals, which could also have enhanced its anti-ulcer activity (Ima et al., 2010; Sabiha et al., 2011; Ateeq et al., 2013). Saponins possess immunomodulatory, anti-inflammatory and vasoprotective effects which could have aided the observed anti-ulcer activity of $H$. indicum (Ima et al., 2010; Sabiha et al., 2011; Ateeq et al., 2013).

The gastro - protective potential of $n$ - hexane fraction of the methanolic extracts of the dried leaves of $H$. indicum against indomethacin-induced ulceration in rats, might in part, be due to its tannins and saponin constituents. Due to in-adequate facilities in our laboratory, the active components responsible for the anti-ulcer activities of $H$. indicum could not be characterized and isolated. Further experiments should be conducted to isolate the active components responsible for the anti-ulcer activities of $\mathrm{H}$. indicum

\section{CONCLUSIONS}

The findings of this study show that the n-hexane fraction of $H$. indicum possessed gastroprotective properties, probably due to the presence of tannins and saponins in its nonpolar components.

\section{REFERENCES}

Adesanwo, J.K., Ekundayo, O., Oluwole, F.S., Olajide, O.A., Van Den Berge, A.J.J. and Findlay, J.A. (2003). The Effect of Tetracera Potatoria and its Constituent Betulinic Acid on Gastric Acid Secretion and Environmentally-Induced Gastric Ulceration. Nigerian Journal of Physiological Sciences 18 (1-2): 21-26.

Akinlolu, A.A., Ayoola, M.D., Otulana, J.O., Akinola, O.B., Abimbola, O. and Ejiwunmi, A.B. (2008). Evaluation of the Histo-Gastroprotective and Antimicrobial Activities of Heliotropium Indicum. Malaysian Journal of Medical Sciences, 15(3): 22-30.

Akinlolu, A.A., Sadiq, M., Ayoola, M.D., Otulana, J.O., Abimbola, O. and Ejiwunmi A.B. (2006). Morphological Gastroprotective Effects of Heliotropium indicum on Gastric Ulcerated Mucosa. Pakistan Journal of Pathology, 17(2): 60 - 64 .

Ashoka, M.S., Shashidhar, C.S. and Prakash, S. (2011). Anti-Ulcer Activity of Heliotropium indicum Leaves Extract. International Journal of Pharmaceutical Sciences and Research, 2(5): 1288-1292.

Ateeq, A., Vinay, K. and Santosh, K.M. (2013). Natural Antiulcer Agents: A pharmacological Review. International Journal of Research in Pharmaceutical and Biomedical Sciences, 4(2): 535-541.

Burkhill, H.M. (1985). The Useful Plants of Tropical West Africa, Volume 1, Royal Botanic Gardens, Kew, UK, Pp $293-295$.

Evans, C.W. and Trease, G.E. (2002). Trease and Evans Pharmacognosy. Sander's Publishing Company, $15^{\text {th }}$ Edition, Pp 221-230.

Evbuonwan, M.I. and Bolarinwa, A.F. (1991). Effect of Diet on Indomethacin Induced Peptic Ulceration in Pregnant Rats. Nigerian Journal of Physiological Sciences, 6:187-196.

Irma, P., Aghieszka, G. and Danuta, S. (2010). Saponins as cytotoxic agents: a review. Phyotchemical Review 9(3): $425-474$.

John, A.T. and Onabanjo, A.O. (1990). Gastroprotective Effects of an Aqueous Extract of Entandro pragmautile Bark in Experimental Ethanol-Induced Peptic 
Ulceration in Mice and Rats. Journal of Ethnopharmacology, 29: 87-93.

John, L.W. (2000). How do NSAID's cause ulcer disease? Bailliere Clinical Gastroenterology, 14(1): 147-159.

Kiernan, J.A. (1990). Histological and Histochemical Methods: Theory and Practice, $2^{\text {nd }}$ edition, Pergamon Press, Exeter, Pp 97 - 98.

Raji, Y., Ogunwande, I.A., Adesola, J.M. and Bolarinwa, A.F. (2001). Anti-diarrhegenic and anti-ulcer properties of Irvingia gabonensis in rats. Pharmaceutical Biology, 39(5): 340-345.

Raji, Y., Udoh, U.S. and Ojo, O.O. (2003). Gastric Ulcerogenic Activities of Piper Guineense Extract in Rats. Nigerian Journal of Physiological Sciences, 18(1-2): 27-30.

Ramzi, S.C., Vinay, K. and Turcker, C. (1999). Robbins' Pathological Basis of Disease, 6th edition, Saunder's Company, Pp 795 - 796.
Rojas, J.J., Ochoa, V.J., Ocampo, S.A. and Muñoz, J.F. (2006). Screening for antimicrobial activity of ten medicinal plants used in Colombian folkloric medicine: A possible alternative in the treatment of nonnosocomial infections. BMC Complementary Alternative Medicine, 17(6): 2. DOI: 10.1186/14726882-6-2.

Sabiha, S., Mohd., A.A., Asif, M. and Aktar, M. (2011). Roles of phenolic compounds in peptic ulcer: An overview. Journal of Pharmaceutical Bioallied Sciences, 3(3): 361-367.

Sofowora, A. (1993). Medicinal Plants and Traditional Medicine in Africa. John Wiley \& Sons, Inc, Pp 195 238. 